\title{
Ataxia-tapetoretinal degeneration syndrome
}

INSERM

\section{Source}

INSERM. (1999). Orphanet: an online rare disease and orphan drug data base. Ataxiatapetoretinal degeneration syndrome. ORPHA:1178

A rare hereditary ataxia characterized by simultaneous onset and development of cerebellar ataxia and chorioretinal degeneration (including macular degeneration, advancing choroidal sclerosis, punctata albescens, and retinitis pigmentosa). There have been no further descriptions in the literature since 1963. 